\title{
Banks' audit committees, audit firm alumni and fees paid to audit firm
}

\author{
Kim Ittonen
}
Department of Accounting and Commercial Law, Hanken School of Economics, Helsinki, Finland

\section{Banks' audit

\author{
Emma-Riikka Myllymäki \\ Department of Accounting, Aalto University, Espoo, Finland, and \\ Per Christen Tronnes \\ University of New South Wales School of Accounting, Sydney, Australia
}

\begin{abstract}
Purpose - This paper focuses on bank audit committees and examines whether audit committee members who are former auditors are associated with the acquisition of audit and non-audit services from their former employers.

Design/methodology/approach - The study empirically examines a sample of large banks that are included in the S\&P Composite 1500.

Findings - The paper reports significantly lower audit fees and a higher proportion of non-audit fees to total fees when the audit committee chair is an alumnus of the incumbent audit firm. Moreover, additional analysis reveals that these findings are stronger for banks with more earnings management.

Research limitations/implications - Overall, the findings indicate that audit firms might consider banks using their alumni as audit committee chairs to be less risky or easier to audit, thus requiring relatively less effort from the auditors. The reduced effort required to audit clients with audit firm alumni on their audit committees then has the effect of reducing the audit fees charged. Alternatively, their auditing experience and cognitive proximity might influence the assessment of the need for auditing or the ability to negotiate lower audit fees on the part of audit firm alumni.

Originality/value - This paper provides empirical evidence of the association between audit firm alumni in influential positions on an audit committee and fees paid to those audit firms in the banking industry. The findings contribute to the literature by suggesting that banks with affiliated former auditors chairing their audit committees not only have significantly lower audit fees but also a higher proportion is spent on nonaudit services.
\end{abstract}

Keywords Audit fees, Banks, Audit committee, Audit firm alumni, Non-audit fees

Paper type Research paper

(C) Kim Ittonen, Emma-Riikka Myllymäki and Per Christen Tronnes. Published by Emerald Publishing Limited. This article is published under the Creative Commons Attribution (CC BY 4.0) licence. Anyone may reproduce, distribute, translate and create derivative works of this article (for both commercial \& non-commercial purposes), subject to full attribution to the original publication and authors. The full terms of this licence may be seen at http://creativecommons.org/licences/by/4.0/ legalcode

We gratefully acknowledge three anonymous reviewers, Vic Naiker, Klaus Holm, and Ray Donnelly for their comments. The paper benefited from comments by participants at the 2016 Auditing Section Midyear Meeting, the 2016 Workshop on Audit Quality, and the 2017 European Auditing Research Network Symposium. Ittonen acknowldedges the funding from the Academy of Finland; Jenny and Antti Wihuri Foundation; the Foundation for Economic Education; and the Finnish Foundation for Share Promotion. 
MAJ

34,7

784

\section{Introduction}

This paper examines whether bank audit committees' decisions on audit and non-audit services (NAS) are influenced by the presence of audit firm alumni[1] on the committee. To the best of our knowledge, this is the first study focusing on audit firm alumni in the banking industry.

During the financial crisis, bank auditors were accused of providing poor quality[2]. Safeguarding auditor independence and audit quality is one of the main purposes of an audit committee (US House of Representatives, 2002). Audit committee oversight is a central element in ensuring that the financial information is reliable. The banking industry is an interesting research setting owing to the high level of audit and NAS fees paid[3] and because of the industry's importance to the economy (Landsman and Peasnell, 2013)[4]. On one hand, the complexity of bank operations and financial processes have the potential to create a greater demand for both audit and NAS. On the other hand, the public's demands for scrutiny of banks might induce audit committees to prioritize audit quality, and to avoid high NAS because of the adverse impact on auditor independence. Consequently, bank audit committee members are under pressure to demonstrate appropriate expertise.

Audit firm alumni have the appropriate expertise to serve on the audit committee and efficiently evaluate the costs and benefits of the services provided by the auditors. However, proximity with the incumbent auditor may increase or reduce the quality of the audit committee decisions (Boschma, 2005; Nooteboom, 1999). Particularly, audit firm alumni that have a higher level of cognitive proximity [5] with the audit firm can communicate with the auditors and understand the audit process, audit risk, and the extent of audit and NAS needed (Marxen, 1996), which could affect the auditors' assessment of audit engagement risk (Basioudis, 2007). Nevertheless, the possible existence of social proximity and organizational identification[6] could adversely impact audit committee effectiveness (Menon and Williams, 2004). Social proximity and organizational identification can cause the audit committee to underestimate opportunism, thus reducing audit committee effectiveness (Boschma, 2005; Lähdesmäki and Suutari, 2012; Menon and Williams, 2004; Uzzi, 1997) or alternatively, reduce auditor skepticism, and thus, impair audit quality (Iyer et al., 1997; Lennox and Park, 2007; He et al., 2017). Consequently, proximity may impact audit and NAS fees[7].

Our sample comprises all banks featured in the S\&P Composite 1500 between 2004 and 2012 and the final sample consists of 663 firm-year observations from 82 individual banks. The empirical findings indicate that banks have significantly higher proportions of nonaudit fees to total fees when their audit committee chair is an audit firm alumnus. Further analysis suggests that a higher proportion of non-audit fees appears to be a result of lower audit fees. Based on previous studies (Basioudis, 2007; Krishnan and Visvanathan, 2009), audit firms can consider banks with one of their alumni serving as the audit committee chair to be less risky or easier to audit, resulting in lower audit fees. Alternatively, the alumni of the incumbent audit firm may be able to negotiate lower audit fees with their previous employer or demand less assurance overall[8].

The additional analyses suggest that among banks with lower earnings quality, audit committees including alumni of the incumbent auditors are positively associated with the proportion of non-audit fees and negatively with audit fees. This finding is in contrast with the expectation that lower audit fees are a result of lower risk. In contrast, the finding may suggest that lower audit fees (effort) may hinder the auditors from identifying and constraining earnings management. Alternatively, social proximity might have resulted in a lack of skepticism, unjustifiably low-risk assessments by the auditors and (or) unjustifiably low demand for audit effort by bank audit committees. 
Our findings contrast with those of Naiker et al. (2013), who report that among a sample of non-financial companies, both unaffiliated and affiliated former audit partners reduce the level and proportion of non-audit fees paid to the incumbent auditors. We consider alternative explanations for the contradictory findings. Firstly, Naiker et al. (2013) examine the years 2004-2005, a period with substantial increases in fees following the implementation of SOX. The trends presented by Audit Analytics (2017) suggest that both audit and non-audit fees (scaled by revenues) have been declining since the data period used by Naiker et al. (2013). Consequently, our results from the banking industry could indicate that audit fees of companies with audit firm alumni on their audit committees have been declining during this period more than those of companies without such directors on the audit committee. Alternatively, our results may suggest that the association between audit firm alumni and fees differs in the banking industry from that in other industries.

Our study contributes to the audit and corporate governance literature. First, previous research has largely ignored the banking industry when investigating audit committee characteristics and fees paid to audit firms. Considering the size and the systemic risk posed by large banks in conjunction with the high levels of non-audit fees and the increased pressure on audit fees after the financial crisis (PCAOB, 2011), audit committees in the banking industry play a particularly important role in ensuring that auditor independence and audit quality are maintained. Our paper, hence, extends prior studies by examining the association of former auditors on large banks' audit committees and the acquisition of audit services and the pre-approval of NAS. Second, our paper potentially extends the literature on cognitive and social proximity. The evidence on the association between having alumni of the incumbent auditors on the audit committee and lower audit fees implies that cognitive proximity may improve the communication and understanding between the audit committees and the auditors. However, our paper also provides support for the importance of social proximity and the organizational identification of audit firm alumni. It is concerning that these findings exist in the context of more aggressive earnings management, thus suggesting that reducing audit fees may have unintended consequences on earnings management. Third, our paper contributes to the call for research on "the role of the audit committee chairs in facilitating effective audit committee performance" (Carcello et al., 2011). Finally, the findings support Bonner et al. (2002) and Tanyi and Smith (2015), by suggesting that chairs with functional experience of auditing and NAS, influence audit committee decision-making more than do ordinary members with similar experience.

\section{Background and hypothesis development}

\subsection{Audit committee responsibilities related to audit and non-audit services}

Audit committees are responsible for overseeing the financial reporting process and ensuring high-quality financial reporting (SEC, 2003a), including the appointment, compensation and supervision of the auditors (US House of Representatives, 2002, Section 301). Specifically, Section 301 mandates audit committees to be directly responsible for determining the audit fees and Section 201 commands that non-prohibited NAS must be approved in advance by the audit committee (US House of Representatives, 2002). Many types of NAS are prohibited as non-audit fees paid to the incumbent audit firm may threaten auditor independence and the actual or perceived audit quality by creating an economic bond between the auditor and the client (Unger, 2001; Abbott et al., 2003)[9]. In terms of nonprohibited NAS, audit committees are given the decision-making role of considering the potential economic benefits of purchasing NAS from the auditors. That is, NAS provided by a firm's auditors have the potential to improve audit work via knowledge spillover. As overseeing the audit process, negotiating the audit fees and pre-approving NAS are the main 
responsibilities of the audit committee, the committee must evaluate the company's relationship with the auditor in conjunction with these tasks.

Ensuring that an auditor provides a high level of assurance on the financial statements of banks may be more challenging than supervising an auditor for a non-financial firm because the complexity of the instruments, operations and financial processes impose greater demands on audit committee members' expertise. The economic importance of the banking industry and the financial crisis illustrate the importance of high-quality auditing in banks. Audit quality encompasses audit expertise and effort and objectivity and independence (DeAngelo, 1981). These aspects may sometimes have conflicting effects on the procurement of services from the auditors and the audit committees may face a trade-off between auditor expertise and independence. For example, incumbent auditors might be selected as providers of NAS because they offer the highest quality of permitted NAS or alternatively, audit committees may believe that sourcing NAS from the incumbent auditors provides knowledge spillovers and operational benefits to the audit engagements (Turner, 2001; Whisenant et al., 2003; Kinney et al., 2004).

\subsection{Audit committees with audit firm alumni and services acquired from the auditors}

If they are to manage their various responsibilities, audit committees should be composed of members with appropriate expertise[10]. Beck and Mauldin (2014) and Brown-Liburd and Wright (2011) provide evidence that powerful audit committees are able to restrict management influence on the auditor-client negotiations. Decisions related to the extent of audit services and whether to purchase NAS from the incumbent audit firm require the expertise of the audit committee members and having worked as an auditor should be a highly relevant source of experience (Naiker and Sharma, 2009; Dhaliwal et al., 2010). Consequently, audit committees involving former auditors are likely to have greater power in audit fee negotiations. Members with auditing experience are also likely to be better able to evaluate the level of audit and NAS needed while recognizing the effects of audit and nonaudit fees on auditor independence and audit quality. Naiker and Sharma (2009) point out that former audit partners have years of direct experience of auditing internal controls and financial statements. Former auditors understand the audit process better than other members and should, therefore, be more competent in assessing the extent of assurance needed. Naiker et al. (2013) argue that directors with accounting and/or auditing backgrounds can be expected to have an in-depth understanding of the nature of different types of NAS. Overall, this type of functional experience could drive negotiations over audit and non-audit fees in different directions. For example, knowing the audit partner compensation structure or how audit firm or partner fee dependence could affect audit quality, puts former auditors in a better position to evaluate the potential effects of a joint provision of audit and NAS on auditors' behavior.

Previous studies suggest that factors such as a shared background and interests can influence business negotiations (Jones, 1991; Wildermuth et al., 2017). Cognitive proximity sharing a common knowledge base and belonging to the same community of practice facilitates efficient communication and improves mutual understanding in new or complex settings (Nooteboom, 1999; Boschma, 2005; Mattes, 2012). Audit committee members who are former auditors share a professional background and knowledge base with the auditors. Consequently, cognitive proximity between the audit firm alumni and the incumbent auditors may improve an audit committee's understanding of the benefits and costs of audit and NAS offered, and facilitate communication about the company's needs to the auditors (Iyer, 1998). These two factors may influence audit and non-audit fees in both directions. 
Audit committee members who are alumni of the affiliated audit firm share a social association or bond with the audit firm and consequently the concept of social proximity might have an impact on the fees paid to the auditors. Audit firms often maintain contact with their former staff through newsletters and events and former colleagues may maintain communication on a personal level (Iyer et al., 1997). Previous studies suggest that social proximity (socially embedded relations between actors) is likely to improve the exchange of knowledge owing to trust, kinship, loyalty and experience (Boschma, 2005; Lähdesmäki and Suutari, 2012; Mattes, 2012)[11]. However, social proximity can on occasion be a disadvantage in that it can lead to opportunism being underestimated or reduced critical evaluation (Uzzi, 1997; Boschma, 2005).

Consequently, the proximity between alumni of the incumbent audit firm and the auditors can affect the effectiveness of the audit committee. Cognitive proximity is likely to improve the communication and exchange of knowledge, whereas social proximity can lead alumni to underestimate opportunism and/or the audit firm to evaluate the engagement risk at a lower level than is appropriate. Supporting this line of thought, previous studies offer evidence that social proximity and loyalty in the form of organizational identification influences the inclination of audit firm alumni to provide economic benefits to their former employer (Iyer et al., 1997; Lennox and Park, 2007). Considering cognitive and social proximity, affiliated former auditors may be inclined to push more profitable NAS toward their former employer and reduce the effort put into the audit, which could have an adverse effect on audit quality.

\subsection{Former auditors and group decision-making}

Advanced functional experience, such as the experience gained from working as an auditor, can affect the overall decision-making and performance of an audit committee in different ways. First, the functional experience is likely to improve the individual members' and the audit committee's performance on tasks related to auditing or tasks requiring a high degree of sophistication, such as complicated technical issues and the accounting of financial instruments (DeZoort, 1998), something that is particularly relevant in large banks. Second, expert members are also likely to have a significant impact on group decision-making when the task is difficult and related to the expert member's specialty, and when other members are aware of that expertise (Bonner et al., 2002). Non-expert members are likely to rely on the expertise of audit firm alumni in audit-related decision-making. Third, we note that the audit committee chair is responsible for setting the meeting agenda, presiding over the meeting and discussion, building and maintaining the information flow between the audit committee, external auditors, internal auditors and management (Beasley et al., 2009; Bédard and Gendron, 2010; Bromilow and Keller, 2011). Tanyi and Smith (2015) show that the roles of the chair and the financial expert are significant to the audit committee, and importantly, that companies with experts chairing the audit committee produce higher quality financial reporting. We, therefore, expect that audit firm alumni serving as audit committee chairs would have a stronger impact on audit committees' audit fee negotiations and pre-approvals of NAS, than when a firm's audit committee is chaired by someone lacking auditing expertise.

\subsection{Hypotheses}

Based on the above discussion, we expect that due to experience and cognitive proximity, the audit firm alumni would be very competent at weighing the benefits of audit and NAS and aware of the threat to auditor independence posed by an excessive proportion of nonaudit fees. However, social proximity may also have an effect; for example, former auditors may be persuaded to push business to auditors in their network. Given these arguments, we state the following null hypothesis: 
MAJ

34,7

788

H1. There is no association between the presence of audit firm alumni on bank audit committees and the non-audit fee ratio.

H2. There is no association between the presence of audit firm alumni on bank audit committees and the level of audit fees.

H3. There is no association between the presence of audit firm alumni on bank audit committees and the level of non-audit fees.

If our expectations are justified, we expect to reject the null hypothesis in favor of one of the alternatives, that is, to find that affiliated and unaffiliated audit firm alumni on bank audit committees have either a negative or a positive association with audit and non-audit fees.

\section{Methodology}

3.1 Sample selection

Our initial sample consists of 819 bank-year observations from the 91 unique banks that are included in the S\&P Composite 1500 index during the post-SOX fiscal years 2004-2012. We review the biographies of the audit committee members on BoardEx to identify whether the members have auditing experience and are alumni of their bank's audit firm. Audit and non-audit fees are derived from Audit Analytics and the governance and financial variables are from Bankscope, Audit Analytics, and Datastream. After eliminating bank-year observations with missing data, our final sample contains 663 bank-year observations from 82 individual banks.

\subsection{Empirical model}

We use a period-fixed panel regression with standard errors clustered on observations from each of the banks to examine the association between banks with former auditors on the audit committees and the fees paid for audit or non-audit services:

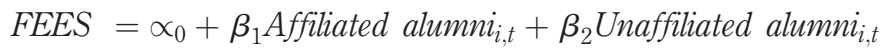

$$
\begin{aligned}
& +\beta_{3} \text { Financial expert }_{i, t}+\beta_{4} \text { Accounting expert }_{\mathrm{i}, t} \\
& +\beta_{5} \text { CEO Chair }{ }_{i, t}+\beta_{6} \text { CEO is CPA }+\beta_{7} \text { CFO is CPA } \\
& +\beta_{8} C F O \text { affiliated with auditor }+\beta_{9} L o g \text { of boardsize } e_{i, t} \\
& +\beta_{10} \text { Board independence }_{i, t}+\beta_{11} \log \text { of } A C \text { size }_{i, t} \\
& +\beta_{12} \text { Proportion of women on } A C_{i, t}+\beta_{13} \log \text { of total assets } s_{i, t} \\
& +\beta_{14} \text { Change in } \text { assets }_{i, t}+\beta_{15} \text { Impaired loans }_{i, t} \\
& +\beta_{16} \text { Tier } 1 \text { ratio }_{i, t}+\beta_{17} \text { Commercial loans }_{i, t} \\
& +\beta_{18} \text { Consumer loans }_{i, t}+\beta_{19} \text { Real estate loans } s_{i, t} \\
& +\beta_{20} \text { Other loans }_{i, t}+\beta_{21} \text { Return on average assets } s_{i, t} \\
& +\beta_{22} \text { Big } 4 \text { auditor }_{i, t}+\beta_{23} \text { Auditor change } i_{i, t} \\
& +\beta_{24} M \& A \text { or restructuring } i, t+\beta_{25} \text { Material weakness }{ }_{i, t} \\
& +\beta_{26} \text { Restatement }_{i, t}+\sum \beta_{27-29} \text { Bank type fixed effects } \\
& +\sum \beta_{30-37} \text { Year fixed effects }+\varepsilon_{i, t}
\end{aligned}
$$


In our main analysis, we estimate this regression in six different specifications, where the dependent variable, FEES, is either the ratio of non-audit fees to total fees, the log of audit fees or the $\log$ of non-audit fees. The test variables, Affiliated alumni and Unaffiliated alumni, capture the auditing experience of either the committee chair or the entire audit committee.

\subsection{Variables of audit firm alumni on the audit committee}

Our test variables capture the presence, previous affiliation and current role of alumni of

audit firms on their bank employers' audit committees. Consistent with Cohen et al. (2014) we use the board members' comprehensive history of work employment provided by BoardEx to classify our test variable. As we are primarily interested in alumni with auditing experience, we define directors with a certified public accountant (CPA) and an employment history at an audit firm as an audit firm alumni[12]. Furthermore, we follow Naiker and Sharma (2009) and Naiker et al. (2013) and separate alumni that are affiliated with the incumbent audit firm and those that are unaffiliated. Finally, following Bédard and Gendron (2010), Bromilow and Keller (2011) and Tanyi and Smith (2015) we run two different models. First, we examine whether having a former auditor as the audit committee chair (Affiliated alumni chair and Unaffiliated alumni chair) is associated with the audit and non-audit fees. Second, we examine whether having affiliated or unaffiliated alumni on the audit committee, either as a chair or as a member (Affiliated alumni and Unaffiliated alumni) is associated with audit and non-audit fees.

\subsection{Control variables}

We control for confounding financial and governance characteristics. We follow SEC (2003a) and previous studies (Carcello et al., 2011; Cohen et al., 2014) and distinguish whether an audit committee member is an Accounting expert or a Financial expert[13]. Moreover, based on previous studies (Krishnan and Visvanathan, 2009; Ittonen et al., 2011; Naiker et al., 2013; Jizi and Nehme, 2018) we include the following controls on management, board and audit committee quality: CEO/chair duality, CEO is CPA, CFO is CPA, CFO affiliated with auditor [14], Log of boardsize, Board independence, Log of AC size and Proportion of women on $A C$. $C E O$ and $C F O$ experience, such as the $C P A$ certificate, may be associated with the banks investment in audit and NAS, as these managers may be in a position to evaluate the benefits of acquired services or influence the processes in a manner that reduces audit effort or the need for NAS. Larger, more independent and more diverse boards and audit committees are more likely to demand higher financial reporting quality, and therefore, those characteristics could affect the demand or supply of audit or NAS.

We include bank size (Log of total assets) and growth (Change in assets) to control for the possibility that the proportion of audit and NAS differs systematically across banks of different sizes, and also changes in relation to their size (Naiker et al., 2013). We expect size and growth to be positively associated with audit and non-audit fees. We control for bank loan portfolio attributes and capital management by including the proportion of Impaired loans and the Tier1 ratio. Boo and Sharma (2008) find that the quality of a loan portfolio is associated with audit fees and Fields et al. (2004) report that capital risk is associated with audit fees, but regarding the NAS purchases, we do not have expectations as to direction. We control for loan portfolio characteristics by including the proportion of Commercial loans, Consumer loans, Real-estate mortgage loans and Other loans of lagged total assets. Profitability (Return on average assets) is expected to be negatively associated with audit and non-audit fees (Frankel et al., 2002) and brand name auditors (Big 4 auditor) are expected to have fee premiums and a larger array of NAS, meaning that clients are more 
likely to purchase NAS from Big 4 audit firms. Auditor change may also be associated with changes in the audit and non-audit fees. Furthermore, we control for changes in the operating environment by including an indicator for mergers, acquisitions and restructuring (M\&A or restructuring)[15]. Mergers and acquisitions or restructuring are expected to increase both audit fees and the demand for NAS. We also include Material weakness and Restatements to control for internal control and financial reporting quality. Finally, we control for Bank type by including indicator variables based on SIC codes for National Commercial Banks (SIC 6021), State Commercial Banks (SIC 6022), Other Commercial Banks (SIC 6029) and Federally Chartered Savings Institutions (SIC 6035). All variables are defined in Table I.

\section{Empirical results}

\subsection{Descriptive statistics}

Panel A of Table II reports the descriptive statistics. The descriptive statistics related to the dependent variables reveal that the average (median) bank pays about $\$ 4.0 \mathrm{~m}(\$ 0.894 \mathrm{~m})$ in audit fees and $\$ 1.6 \mathrm{~m}(\$ 0.190 \mathrm{~m})$ in non-audit fees[16]. The average (median) proportion of non-audit fees of total fees is 0.190 (0.177), with the maximum reaching 0.671[17]. About 40 per cent of the banks in the sample have at least one former auditor on the audit committee (Affiliated alumni + Unaffiliated alumni), but only about 6 per cent have former auditors who are affiliated with the incumbent audit firms. Similarly, we observe that about 16 per cent of the banks have a former auditor chairing their audit committee (Affiliated alumni chair + Unaffiliated alumni chair), but only about three percent have audit committee chairs who are affiliated with the incumbent auditors.

Turning to other control variables, the statistics reveal that about 53 per cent of the banks have a CEO who also serves as the chair of the board. The majority (57 per cent) of CFOs are CPAs and about 14 per cent have had an affiliation with the incumbent audit firm. The mean value of bank size ( $\log$ of total assets) in our sample is about 7.171, which translates to about $\$ 1,301 \mathrm{~m}$ of total assets. The average loan portfolio contains predominantly Real-estate loans (about 41 per cent). The Impaired loans are about 1.1 per cent of lagged assets, and the Tier 1 ratio is about 12.2, on average. Most banks use a Big 4 audit firm and about 4 per cent had changed the audit firm. Only 2.4 per cent received a report for material weakness from the auditor, while 9 per cent had a restatement.

In Panel B of Table II, we compare the variable means of banks with former auditors on the audit committee to those with no such directors. Banks with no former auditors on the audit committee have a significantly higher audit and non-audit fees than banks with former auditors. The results further show that banks with former auditors have a significantly higher likelihood of the CEO and CFO having a CPA, and the CFO having been affiliated with the incumbent audit firm. Interestingly, banks with former auditors have on average higher proportions of Real-estate loans and Impaired loans, they are more likely to use a Big 4 audit firm and less likely to get Material weakness reports. We rely on the multivariate analysis to test our hypotheses[18].

\subsection{Main analysis}

Table III presents the results from our main analysis examining the association between banks with audit firm alumni on the audit committee and the ratio of non-audit fees to total fees [Columns (1) and (2)], log of audit fees [Columns (3) and (4)] and log of non-audit fees [Columns (5) and (6)]. That is, with each dependent variable, we estimate two models: In Model 1, we focus on the expertise of the chairs of the audit committees, and in Model 2, on 
Definition

Test variables

Affiliated alumni

Unaffiliated alumni

Affiliated alumni

chair

Unaffiliated alumni

chair

Dependent variables

Log of audit fees

Log of non-audit fees

The ratio of nonaudit

fees to total fees

Control variables

Financial expert

Accounting expert

Financial expert chair

Accounting expert

chair

$\mathrm{CEO} /$ chair duality

CEO is CPA

$\mathrm{CFO}$ is $\mathrm{CPA}$

CFO affiliated with

the auditor

Log of boardsize

Board independence

Log of AC size

Proportion of women

on $\mathrm{AC}$

Log of total assets

Change in assets

Impaired loans

Tier1 ratio

Commercial loans

Consumer loans

Real-estate loans

Other loans

Return on average

assets

Big 4 audit firm
Equals to 1 if, based on BoardEx biographies, at least one of the audit committee members is a CPA with an employment history at the incumbent audit firm, zero otherwise

Equals to 1 if, based on BoardEx biographies, at least one of the audit committee members is a CPA with an employment history at an audit firm other than the incumbent audit firm, zero otherwise

Equals to 1 if, based on BoardEx biographies, the audit committee chair is Affiliated alumni, zero otherwise

Equals to 1 if, based on BoardEx biographies, the audit committee chair is Unaffiliated alumni, zero otherwise

Log of audit fees in dollars

Log of non-audit fees dollars

Non-audit fees divided by total fees

Equals to 1 if, based on BoardEx biographies, at least one of the audit committee members, who is not alumni or accounting expert, is a bank designated financial expert, 0 otherwise

Equals to 1 if, based on BoardEx biographies, at least one of the audit committee members, who is not alumni is an accounting financial expert, 0 otherwise

Equals to 1 if, based on BoardEx biographies, the audit committee chair, who is not alumni or accounting financial expert, is a bank designated financial expert, 0 otherwise

Equals to 1 if, based on BoardEx biographies, the audit committee chair, who is not alumni, is an accounting financial expert, 0 otherwise

Equals to 1 if the $\mathrm{CEO}$ also serves as the board chair, 0 otherwise

Equals to 1 if the $\mathrm{CEO}$ is a $\mathrm{CPA}, 0$ otherwise

Equals to 1 if the $\mathrm{CFO}$ is a $\mathrm{CPA}, 0$ otherwise

Equals to 1 if the CFO was previously affiliated with the incumbent audit firm, 0 otherwise

Log of the number of members on the board of directors

Proportion of board members that are independent

Log of the number of members on the audit committee

Number of women divided by audit committee size

Log of total assets in thousands of dollars

Change in assets from $t-1$ to $t-0$ divided by lagged assets

Impaired loans divided by lagged total assets

Tier 1 capital ratio

Commercial loans divided by lagged assets

Consumer loans divided by lagged assets

Real-estate loans divided by lagged assets

Other loans divided by lagged assets

Return on three-year average total assets

Equals to 1 if the audit firm is one of the four largest audit firms, 0 otherwise

(continued)
Banks' audit committees

791 
Definition

\begin{tabular}{ll}
\hline $\begin{array}{l}\text { Auditor change } \\
\text { M\&A or } \\
\text { restructuring }\end{array}$ & $\begin{array}{l}\text { Equals to } 1 \text { if the bank has changed the auditor from } t-1 \text { to } t-0,0 \text { otherwise } \\
\text { Equals to } 1 \text { if the bank is engaged in a merger or acquisition based on the Audit } \\
\text { Analytics internal control data indicating exemptions to the internal control } \\
\text { assessment or if the bank reported restructuring charges, } 0 \text { otherwise }\end{array}$ \\
$\begin{array}{ll}\text { Material weakness } \\
\text { Equals to } 1 \text { if the bank has material weaknesses in the internal controls, } 0\end{array}$ \\
$\begin{array}{l}\text { Restatement } \\
\text { Bank type }\end{array}$ & $\begin{array}{l}\text { otherwise } \\
\text { Equals to } 1 \text { if the bank has issued a restatement, 0 otherwise } \\
\text { Indicator variables for National Commercial Banks (SIC 6021), State } \\
\text { Commercial Banks (SIC 6022), Other Commercial Banks (SIC 6029) and } \\
\text { Table I. }\end{array}$ \\
\hline
\end{tabular}

the presence of audit firm alumni on the audit committee in general (either as the chair or as a member).

The results on the non-audit fee ratio indicate a positive and significant $(p<0.01$, twotailed) association with Affiliated alumni chair (Model 1). The coefficient implies that the non-audit fee to total fee ratio of banks with an Affiliated alumni chair is about 13 per cent higher than for banks without an auditor alumnus serving as the chair of the audit committee. Moreover, the Wald test reveals that the coefficient for Affiliated alumni chair is significantly ( $p<0.05$, two-tailed) larger than the coefficient for Unaffiliated alumni chair, suggesting that banks with Affiliated alumni chair approve significantly higher proportions of non-audit fees than do banks with Unaffiliated alumni chair. The test variables are insignificant in Model 2. Consequently, we partly reject the null hypothesis and conclude that banks with audit committees chaired by alumni of the incumbent auditors procure a larger proportion of NAS from the auditors.

Turning to the results in Columns (3) and (4) of Table III, we find a significant negative association between affiliated alumni and audit fees. The association is more pronounced when the affiliated alumni chair the audit committee (significance $p<0.01$, two-tailed, Model $1)$, although it is still marginally significant for affiliated alumni in general $(p<0.1$, twotailed, Model 2). The coefficients suggest that audit fees are about 9 per cent lower if there are affiliated audit firm alumni on the audit committee and 14 per cent lower when the committee is chaired by an audit firm alumnus. The variables relating to unaffiliated alumni are insignificant. The Wald test indicates that the coefficients for affiliated and unaffiliated former auditors are significantly different ( $\phi<0.05$, two-tailed), but only in Model 1 (chairs). Consequently, it is possible that affiliated alumni either improve the quality of financial reporting or internal controls to the extent that the audit requires less effort; have the expertise that helps them resist commissioning components of the audit that are not value enhancing; or are able to negotiate lower audit fees with their former colleagues. In Columns (5) and (6) of Table III, we tabulate the results from the log of the non-audit-fee model. The results indicate that the expertise of either audit firm alumni or audit committee members are not significantly associated with the level of non-audit fees[19].

These findings suggest that affiliated audit firm alumni approve a higher proportion of non-audit fees when appointed the chair of a bank audit committee. Higher proportions of non-audit fees are typically considered a potential threat to auditor independence; however, the evidence reveals that the higher proportion of non-audit fees is a result of a significantly lower level of audit fees. The findings that the characteristics of the directors chairing the audit committee are more strongly associated with audit committee decisions are consistent 


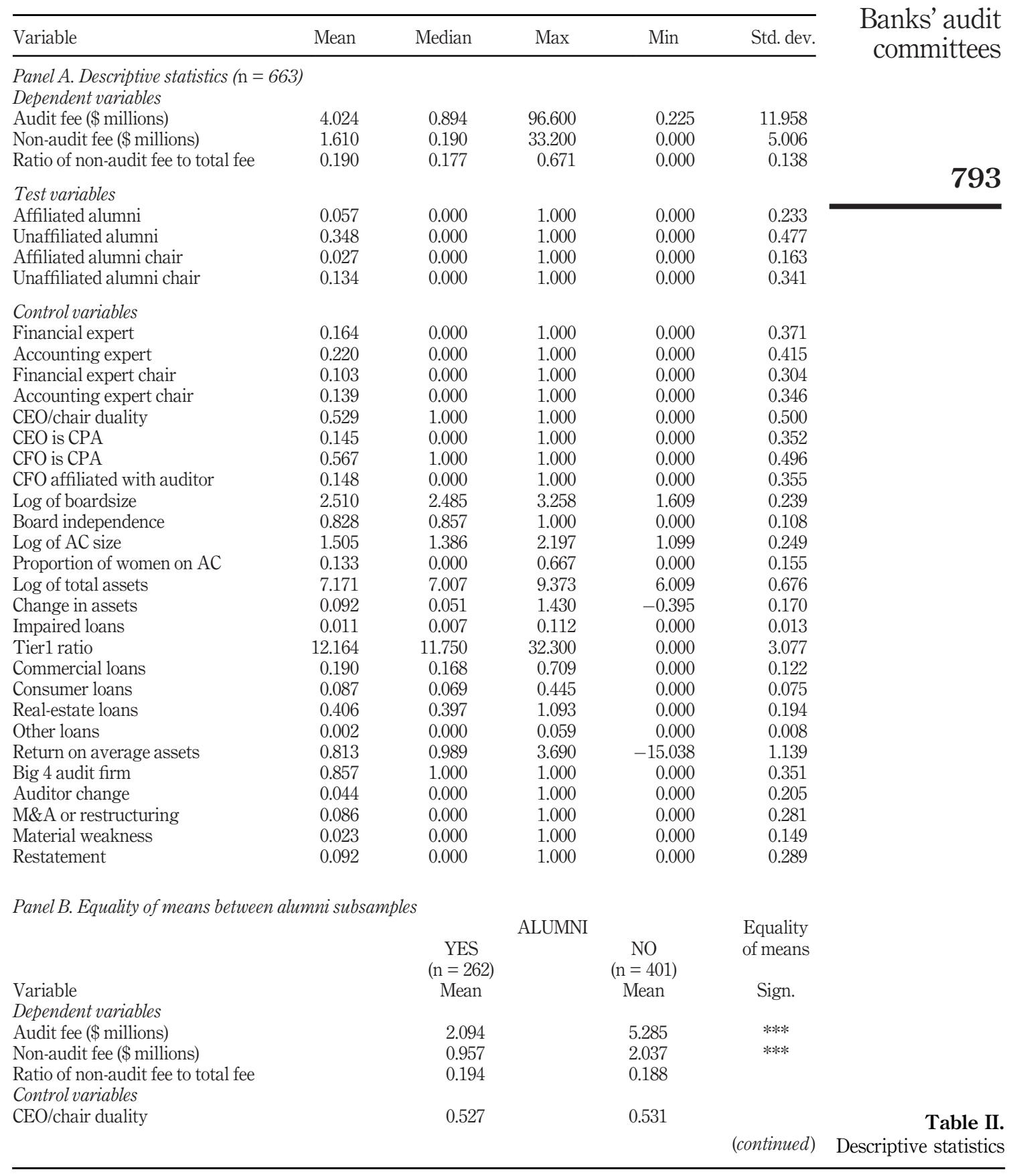


MAJ

34,7

$\mathrm{CEO}$ is $\mathrm{CPA}$

\section{CEO is CPA}

CFO is CPA

CFO affiliated with auditor

\subsection{6}

0.660

0.260

Log of boardsize

Board independence

Log of AC size

794

Proportion of women on AC

2.516

0.834

1.520

0.141

7.143

Log of total assets

Change in assets

Impaired loans

Tier1 ratio

Commercial loans

Consumer loans

Realestate loans

Other loans

Return on average assets

Big 4 audit firm

Auditor change

M\&A or restructuring

Material weakness

Restatement

$\begin{array}{rr}0.072 & * * * \\ 0.506 & * * * \\ 0.075 & * * * \\ 2.506 & \\ 0.824 & \\ 1.494 & \\ 0.128 & \\ 7.189 & \\ 0.085 & \\ 0.010 & * * * \\ 12.184 & \\ 0.190 & \\ 0.087 & \\ 0.383 & * * * \\ 0.003 & * * \\ 0.839 & \\ 0.823 & * * * \\ 0.045 & \\ 0.125 & * * * \\ 0.032 & * * \\ 0.100 & \end{array}$

Table II.

Notes: All $p$-values two-tailed and calculated from a test of equality of means. *, ** and *** denote $p<0.1$; $p<0.05$; and $p<0.01$, respectively

with Bonner et al. (2002), Bédard and Gendron (2010), Bromilow and Keller (2011) and Tanyi and Smith (2015), which highlights the important impact of expert chairman.

\section{Additional analysis}

\subsection{Financial crisis}

The global financial crisis had severe effects on the banking industry and auditing. Ettredge et al. (2014) found evidence of a significant decrease in audit fees in 2008, the first year of the recent global financial crisis. We examine how the financial crisis affects the association between audit firm alumni on audit committees and fees paid to the auditors.

Panel A of Table IV reports the results for the pre-crisis period (2004-2007). Affiliated alumni (both Affiliated alumni chair and Affiliated alumni) appear to have significantly higher non-audit fee ratios $(p<0.01$, two-tailed) and significantly lower audit fees $(p<0.05$ and $p<0.01$, two-tailed). Again, there is no association with the level of non-audit fees. Moreover, the findings indicate that in the pre-crisis period the Unaffiliated alumni of the audit firm on the audit committees are associated with significantly lower levels of audit fees $(p<0.01$, two-tailed) and non-audit fees $(p<0.1$, two-tailed), but not the Unaffiliated alumni chair. Finally, Panel B of Table IV presents the results for the period of global recession (2008-2012). Consistent with the main analysis and the pre-crisis period, the Affiliated alumni chair is associated with significantly higher non-audit fee ratios $(p<0.01$, two-tailed) and lower audit fees ( $p<0.05$, two-tailed). In summary, the positive association between affiliated alumni chairs and the non-audit fee ratio and the negative association between affiliated alumni chairs and the level of audit fees are prevalent both before and after the financial crisis. 


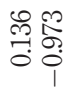

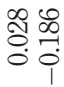

挡 8

\&

今ิ $\infty$

离 $\frac{10}{0}$

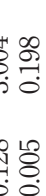

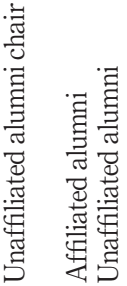

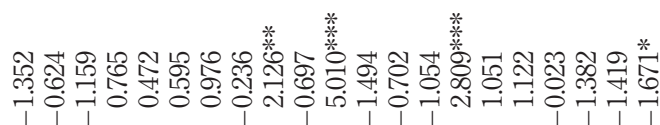

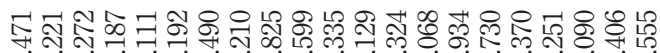

页

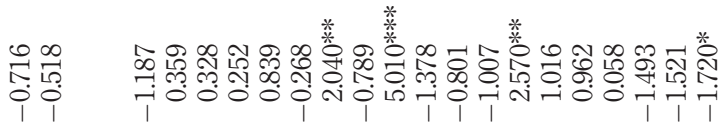

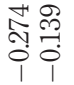

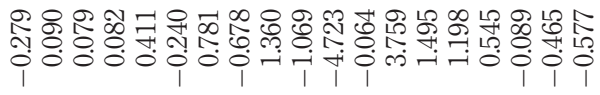

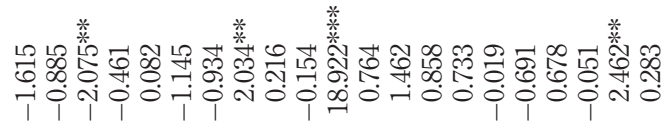

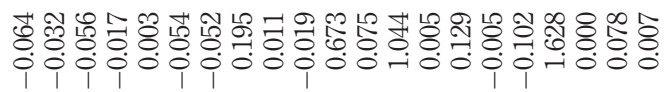

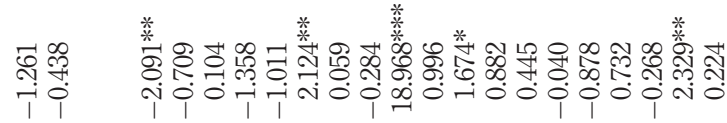

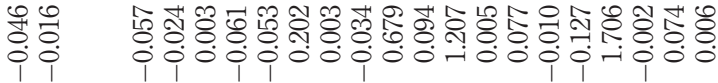

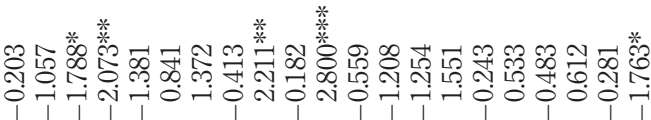

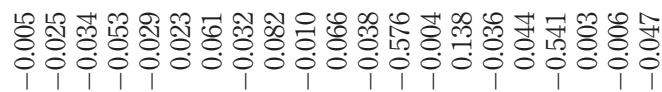

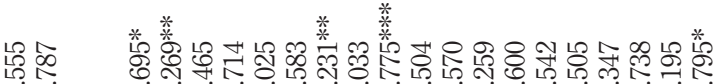

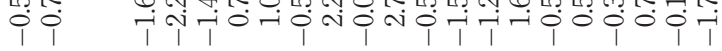

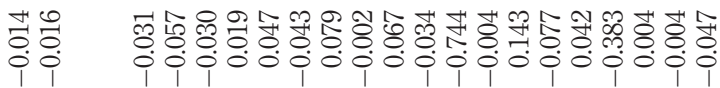

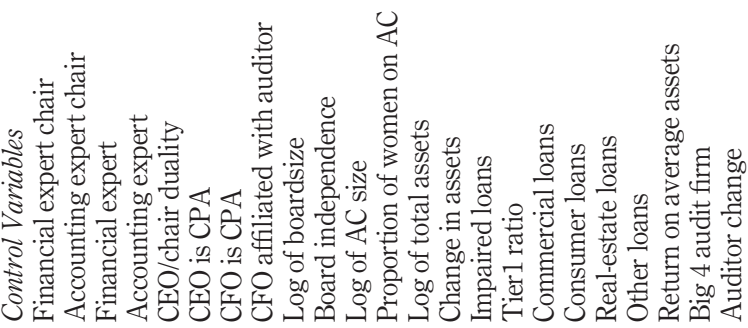

Banks' audit

committees

795

Table III.

Main analysis 
MAJ

34,7

796

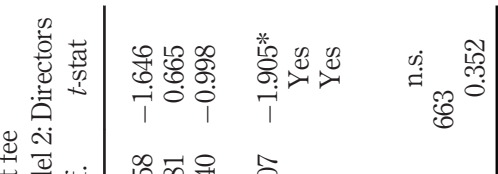

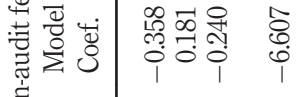

范

总葋

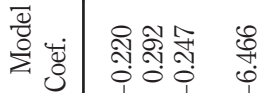

焉焉

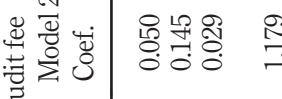

긍

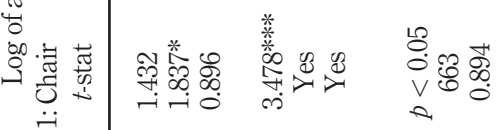

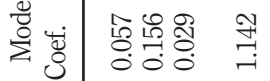

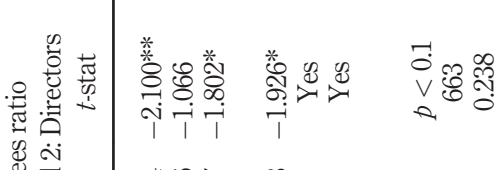

푱

용

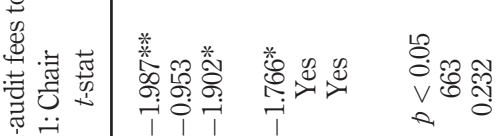

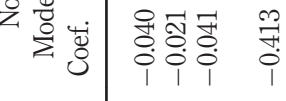

Table III. 


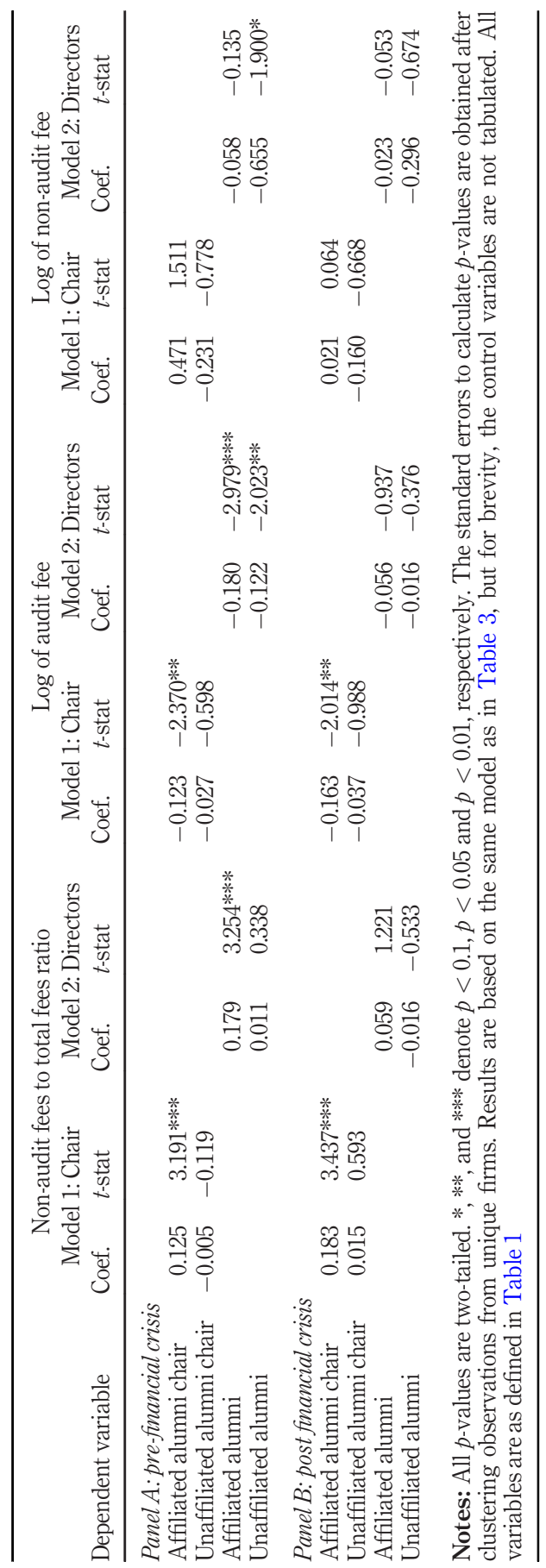

Banks' audit committees

797

Table IV.

Additional analysis: pre and post financial crisis 
MAJ

34,7

798

\subsection{Fees and earnings quality}

As previously mentioned, affiliated alumni serving on audit committees might cause concern about the ability of audit firms to remain independent, and their willingness to withstand client pressure. Ittonen et al. (2018) show that bank audit committees including former auditors are negatively associated with earnings management. To further examine the relations between former auditors on audit committees and fees paid to the incumbent audit firm, we test whether our main findings are affected by the level of earnings quality. Following Naiker et al. (2013), we test this by dividing our sample into two groups based on the median of the absolute value of discretionary loan loss provisions (DLLP). DLLP has previously been used as a measure of banks' earnings management and audit quality (Kanagaretnam et al., 2010; DeBoskey and Jiang, 2012)[20].

Panel A of Table $\mathrm{V}$ presents the results for the sample with higher absolute values of discretionary loan loss provision, that is, greater earnings management. The results show that Affiliated alumni chair and Affiliated alumni are positively and significantly $(p<0.01$, two-tailed) associated with the non-audit fee ratio and negatively and significantly $(p<0.05$ and $p<0.1$, two-tailed) with audit fees. Panel B of Table V indicates that, in the sample with lower absolute values of DLLP (i.e. less earnings management), an Affiliated alumni chair is positively and marginally significantly $(p<0.1$, two-tailed) associated with the non-audit fee ratio. Moreover, both Affiliated alumni chair and Affiliated alumni are negatively and significantly $(p<0.1$ and $p<0.01$, two-tailed) associated with audit fees. Interestingly, the coefficients of Affiliated alumni chair are much higher and more significant in the sample with more earnings management. Overall, these results provide some evidence that audit committees including affiliated former auditors pre-approve higher proportions of non-audit fees and pay lower audit fees when the bank appears to have more earnings management. Consequently, the findings further suggest that social proximity and organizational identification might drive the association between audit firm alumni on the audit committee and the fees paid to the audit firm.

\subsection{Robust regression results}

Because of a skewed distribution of audit fees, non-audit fees and the ratio of non-audit fees to total fees, we run a robust regression using the least absolute value (LAV) regression, which is less sensitive to outliers in the data than an OLS regression (Wooldridge, 2009). The results presented in Panel A of Table VI confirm the positive and significant $(p<0.01$, twotailed) association between Affiliated alumni chair and the non-audit fee ratio. Moreover, the LAV regression also confirms the negative and significant $(\phi<0.01$, two-tailed) association between Affiliated alumni and the audit fees. Interestingly, we also report a positive and significant ( $p<0.01$, two-tailed) association between Affiliated alumni chair and the level of non-audit fees, suggesting that the fees banks incur for NAS are significantly larger if the chair of the audit committee is an affiliated former auditor.

\subsection{Change analysis}

We acknowledge the counterintuitive possibility that our results suffer from endogeneity problems, specifically that former auditors self-select into banks with lower audit fees or higher non-audit fees. Consequently, we identify changes in the composition of audit committees that involve appointing or releasing alumni auditors and create a variable we call Alumni change. During our sample period, there are 26 changes ranging from no former auditors on the audit committee to at least one (Alumni change $=1$ ) and six changes from at least one to none (Alumni change $=-1$ ). Given the low number of changes in our sample, we are unable to separate the changes to reflect whether they affected affiliated and unaffiliated 


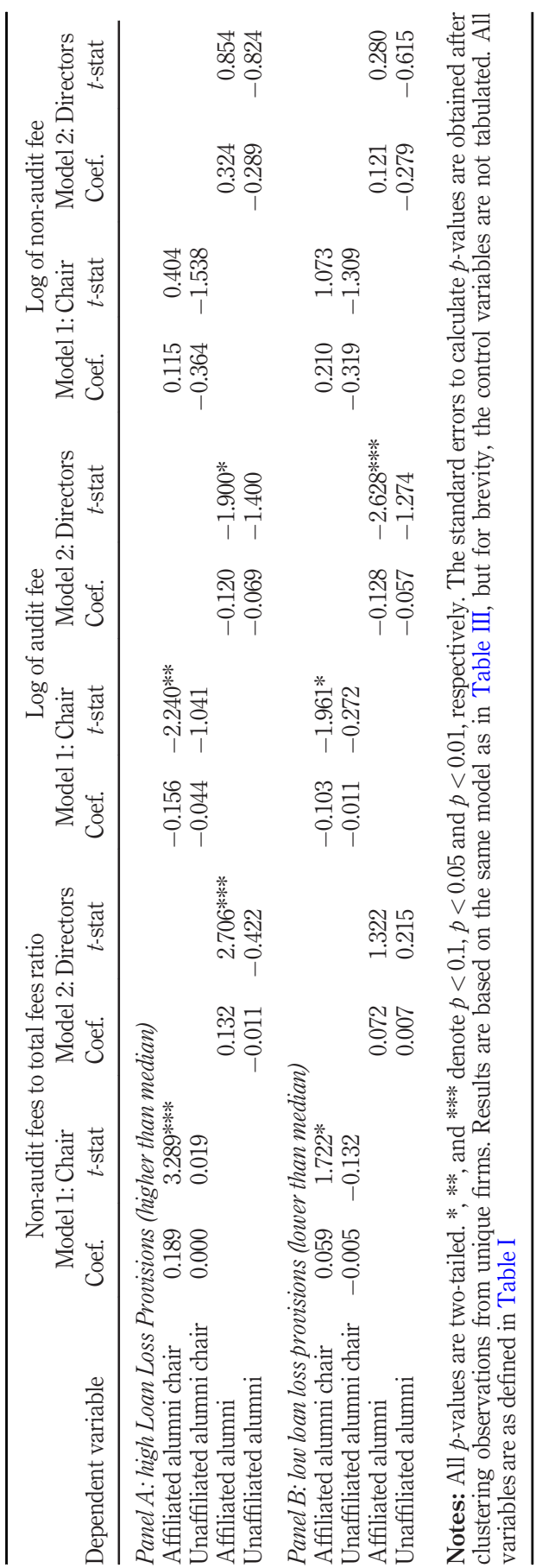

Banks' audit committees 
MAJ

34,7

800

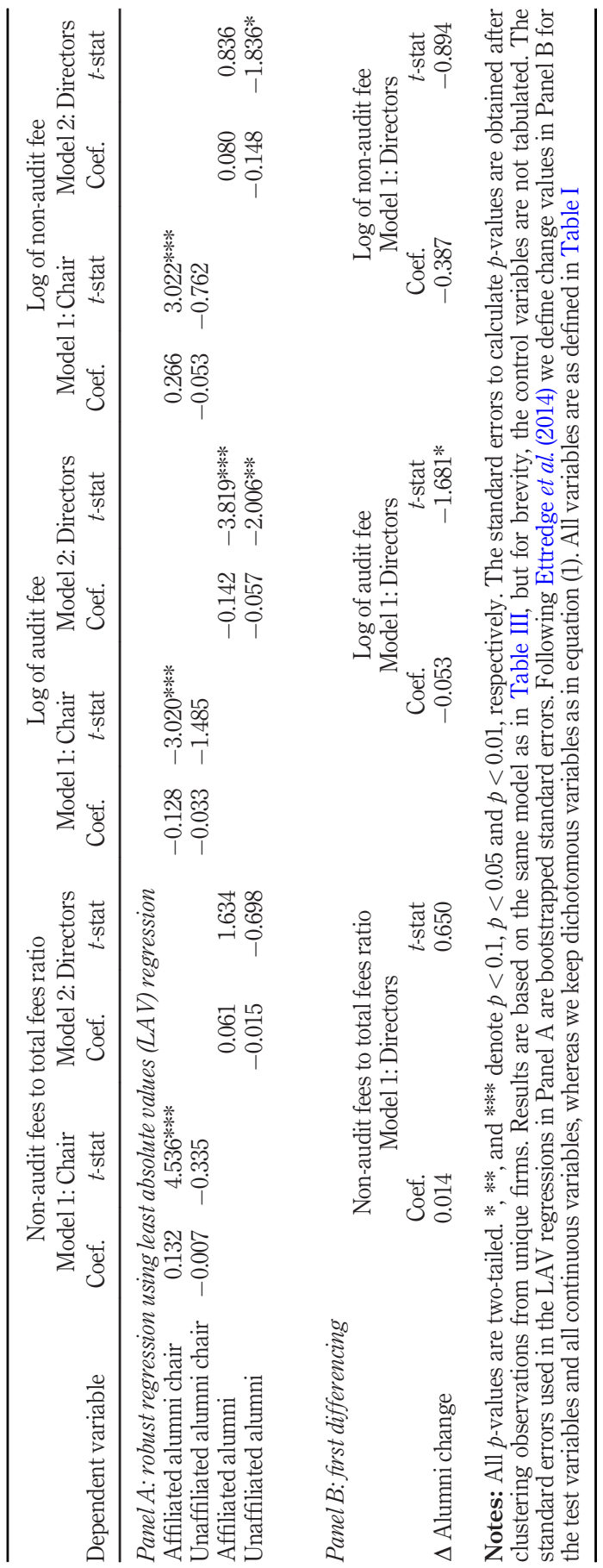

Table VI.

Sensitivity analysis 
auditors or the chair. Panel B of Table VI shows that Alumni change is negatively and significantly ( $\phi<0.1$, two-tailed) associated with audit fees, but not with non-audit fees or the non-audit fee ratio. This suggests that the appointment of audit firm alumni to the audit committee reduces audit fees, and moreover, that it is unlikely that our results are driven by former auditors self-selecting into banks with lower fees or that banks with lower fees appoint former auditors[21].

\section{Conclusions}

This paper examines the association between audit committees with audit firm alumni and the procurement of audit and non-audit services in large banks. While audit firm alumni are likely to possess the necessary functional experience to make a positive impact on audit committee performance in ensuring high-quality financial reports, the influence they have over the procurement of audit and non-audit services may be more multifaceted, particularly in the case of audit committee members who are alumni of the incumbent audit firm.

We extend Naiker et al. (2013) by examining the acquisition of audit services and preapproval of NAS in large banks. The banking industry is interesting because recent history suggests that risk-taking, short-termism and complex financial instruments contributed to the development of the financial crisis. Bank audit committee members must have a high level of accounting and financial expertise to understand complex financial reporting processes. We also extend previous studies by investigating whether bank officers with auditing experience who chair the bank's audit committee are more strongly associated with the acquisition of audit services and the pre-approval of NAS (Bonner et al., 2002; Tanyi and Smith, 2015).

Our findings indicate that audit committees including affiliated alumni, particularly those where an affiliated alumnus holds the chair, are associated with lower audit fees and higher proportions of non-audit fees. Interestingly, the additional findings indicate that this association is stronger in the context of greater earnings management. Overall, our results suggest that banks with affiliated alumni on the audit committee procure less audit services and commission a larger proportion of NAS from the incumbent audit firm than do banks whose audit committees are not chaired by experts. These findings contrasts with those of Naiker et al. (2013), who investigate a sample of non-financial companies during 2004-2005 and find that both affiliated and unaffiliated alumni are negatively associated with non-audit fee ratios. The contradictory findings imply either that the behavior of directors who are audit firm alumni has changed after the initial SOX years (i.e. during a period when audit and non-audit fees scaled by revenue have declined from the 2004-2005 levels) or that the special characteristics of companies in the banking industry influence individual directors' behavior, and therefore, the association between audit firm alumni and fees is different in the banking industry.

Importantly, this study is the first to examine the acquisition of audit services and the preapproval of NAS by the audit committees of large banks. The paper also extends the audit and corporate governance literature (Naiker et al., 2013) by showing that audit firm alumni on audit committees may, on average, behave differently in banks and industrial firms. Moreover, our results extend the proximity literature (Boschma, 2005; Nooteboom, 1999) and that addressing corporate governance (Iyer et al., 1997; Lennox and Park, 2007) by suggesting that while the cognitive proximity between audit firm alumni serving on bank audit committees and the incumbent auditors may reduce audit fees by improving the communication between the audit committees and the auditors, social proximity could pose a threat to auditor independence as a result of reduced demands for assurance and greater proportions of NAS. Finally, we confirm previous findings (Bonner et al., 2002; Tanyi and Smith, 2015) by showing that audit committee chairs with expertise have a significant influence on group decision-making. From an institutional perspective, our findings support regulations (SEC, 2003b) mandating cooling-off 
periods affecting the appointment of audit firm alumni as independent members of the boards of clients of the audit firm that employed them.

\section{Notes}

1. "Audit firm alumni" refers to directors that have a CPA and an employment history at the incumbent audit firm.

2. Accusations went as far as to suggest auditors were, "actively facilitating fraud" or "performing no audit at all' (see e.g. New York state Supreme Court, No. 451586/2010 and Southern District of New York, No. 08-md-01963).

3. In total, 26 of the 50 largest audit fee paying companies in 2016 are from the banking industry. Despite this, the auditing literature, e.g. Naiker et al. (2013), typically excludes companies from the banking sector.

4. Banking crises are costly, for example, Bordo et al. (2001) estimate losses of around 6 per cent of GDP associated with the banking crises, whilst Laeven and Valencia (2013) document losses of about 30 per cent of GDP during the global financial crises of 2007-2009.

5. Cognitive proximity, that is, sharing a common knowledge base, improves mutual understanding and communication between actors (Boschma, 2005; Nooteboom, 1999).

6. Mael and Ashforth (1992) define organizational identification "as a perceived oneness with an organization and the experience of the organizations successes and failures as one's own".

7. The example of IndyMac illustrates the potential problem. Prior to the IndyMac bankruptcy filing in July 2008, EY failed to either identify or report misleading company filings. The chairman of the IndyMac audit committee was Hugh M. Grant, a former auditor, retired vicechairman and the former regional managing partner of the EY Los Angeles office, which became the IndyMac auditor in 2001, a year after Mr Grant was appointed to IndyMac. Owing to Mr Grant's auditing experience, the audit committee appeared to have the tacit knowledge and expertise required to manage the audit committee. However, the social and cognitive proximity between the audit committee chair and the audit firm may have had an impact on the audit and NAS purchases. Interestingly, preceding the bankruptcy, IndyMac reported an abnormally high non-audit fee to total fee ratio (0.54) for 2007 (0.67 in 2006). The average non-audit fee to total fee ratio for S\&P1500 companies during 2006-2007 was based on Audit Analytics data, about 0.19 for banks and 0.15 for non-banks.

8. There are three major players in audit fee negotiations, namely, management, the auditor and the audit committee (Beasley et al. 2009). Beck and Mauldin (2014) provide evidence that audit committee power impacts audit fee negotiations. Consequently, our results may suggest that client negotiation power and ability to reduce audit firm profits could be higher when audit committee chairs are alumni of the audit firm.

9. The findings in the prior studies on the association between NAS and audit quality are mixed. Some studies provide evidence that non-audit fees are associated with lower quality (Frankel et al., 2002; Srinidhi and Gul, 2007), but most studies do not find such an association (DeFond et al., 2002; Ashbaugh et al., 2003; Chung and Kallapur, 2003; Kinney et al., 2004; Mitra, 2007; Habib, 2012). Krishnan et al., (2005) and Francis and Ke (2006) show that non-audit fees are negatively associated with the market evaluation of earnings, suggesting that NAS are a threat to perceived independence. Kanagaretnam et al. (2010) suggest that fee dependence is negatively associated with earnings quality in the banking industry.

10. SEC (2003a) requires disclosure of whether the company's audit committee has at least one financial expert, and the New York Stock Exchange listing requirements (2009) require that the members must be (or become) financially literate, and at least one member must have accounting or related financial expertise. In prior studies, audit committee members' financial, accounting 
and auditing expertise have been found to be positively associated with the effectiveness of the audit committees of non-financial companies ( Abbott et al., 2003; Carcello and Neal, 2003; Krishnan and Visvanathan, 2008; Dhaliwal et al., 2010; Carcello et al., 2011; Krishnan et al., 2011; Cohen et al., 2014; Seetharaman et al., 2014). Because of the SEC (2003a) requirement that companies must disclose whether their audit committee has at least one financial expert, many prior studies have focused on examining this type of general financial expertise and found an association with higher reporting quality (Abbott et al., 2003; Bédard et al., 2004; Carcello et al., 2011). More recent studies have provided evidence that accounting expertise rather than general financial expertise has a positive impact on financial reporting quality (Krishnan and Visvanathan, 2008; Dhaliwal et al., 2010; Schmidt and Wilkins, 2013).

11. Related to this stream of literature are the prior studies investigating social ties between board and management (Hoitash, 2011; Bruynseels and Cardinaels, 2014; Cohen et al., 2017).

12. Naiker et al. (2013) separate former audit partners and other former auditors. The BoardEx biographies do not make this distinction. Consequently, we classify all directors with a CPA and a tenure at an audit firm equally, regardless of their rank in the audit firm. We are aware of the possibility that although a person has a CPA and worked for an audit firm, that person may not have worked on any audit engagements before becoming a director. While these factors may be considered limitations, we believe that they would, at most, bias our results towards not finding support to reject the null hypothesis.

13. Consistent with Cohen et al. (2014) we search director biographies from BoardEx and define members who are not former auditors but have experience as a chief financial officer, chief accounting officer, controller, treasurer or vice president finance, as accounting financial experts (Accounting expert chair and Accounting expert). Committee chairs who are bank designated financial experts are classified under Financial expert chair.

14. The sample does not include any CEO affiliated with auditor.

15. This information is derived from Audit Analytics' internal control data, which indicates if an exemption to the internal control assessment was identified, and whether the exemption is due to an acquisition during the previous year. The information about restructuring is obtained from Data stream.

16. The maximum fees in our sample were paid by Bank of America to PwC: $\$ 96.6 \mathrm{~m}$ of audit fees in $2011, \$ 33.2 \mathrm{~m}$ of non-audit fees in 2009 and $\$ 128 \mathrm{~m}$ of total fees in 2009. For comparison, Naiker et al. (2013) reports an average non-audit fee of about $\$ 1.1 \mathrm{~m}$ for non-financial firms in 2004-2005, whereas we estimate from the Audit Analytics (2017) report that that the mean non-audit fee for accelerated filers in the period like ours (2004-2012) is about $\$ 0.869 \mathrm{~m}$. Consequently, this confirms that the banks in our sample purchase significantly higher levels of NAS than average accelerated filers.

17. US Bancorp had a NAF_RATIO of 0.671 in 2007 - paying EY $\$ 13.9 \mathrm{~m}$ in non-audit fees and $\$ 20.7 \mathrm{~m}$ in total fees. The average $N A F \_R A T I O$ reported by Naiker $e$ al. (2013) is 0.304 and in Audit Analytics (2017) about 0.21. Consequently, the ratio of non-audit fees to total fees is significantly lower in our banking sample than in the Naiker et al. (2013) non-financial sample and the Audit Analytics (2017) accelerated filer sample. This indicates that while the level of nonaudit fees is higher for banks than for the average accelerated filer, their audit fees are generally even higher, thus resulting in lower NAF ratios.

18. The correlations (untabulated) between our variables of interest and the other independent variables used in the models are relatively low (all less than 0.250). Consequently, multicollinearity that potentially could result in excessively inflated standard errors does not appear to be of major concern.

19. As previously mentioned, we expect that regardless of rank and tenure, the experience and expertise gained from auditing, together with the potential cognitive social proximity with the audit firm, differentiate audit firm alumni from other audit committee members. To test whether the rank of former auditors' drives these findings, we run the main analysis first on a sample 
MAJ

34,7

\section{4}

where alumni auditors are former audit partners and then on a sample where alumni auditors are non-partners. The results (untabulated) in both samples are similar to the main findings, and therefore, they support our expectation that the rank of the audit firm alumni does not significantly drive the results.

20. Following Kanagaretnam et al. (2010) and DeBoskey and Jiang (2012), we estimate DLLP by taking the ordinary least squares residual after regressing loan loss provisions (LLP) on nonperforming loans (NPL), loan loss reserves (LLR), change in non-performing loans $(\triangle \mathrm{NPL})$, net loan charge-offs (NLC), change in total loans ( $\triangle$ LOANS), total loans (LOANS) and fiscal year dummies (YEAR). We estimate DLLP separately for four types of banks, based on the banks' SIC codes: National Commercial Banks (SIC 6021), State Commercial Banks (SIC 6022), Other Commercial Banks (SIC 6029) and Federally Chartered Savings Institutions (SIC 6035).

21. We acknowledge that while first differencing is useful in controlling for unobservable timeinvariant factors between banks, it does not control for all unobservable factors, and as such only mitigates endogeneity concerns.

\section{References}

Abbott, L.J., Parker, S., Peters, G.F. and Raghunandan, K. (2003), "An empirical investigation of audit fees, nonaudit fees and audit committees”, Contemporary Accounting Research, Vol. 20 No. 2, pp. 215-234.

Ashbaugh, H., LaFond, R. and Mayhew, B.W. (2003), "Do nonaudit services compromise auditor independence? further evidence", The Accounting Review, Vol. 78 No. 3, pp. 611-639.

Audit Analytics (2017), "Audit Fees and Non-Audit Fees: A Fifteen-Year Trend,", Audit Analytics: Sutton, MA.

Basioudis, I.G. (2007), "Auditor's engagement risk and audit fees: the role of audit firm alumni”, Journal of Business Finance and Accounting, Vol. 34 Nos 9/10, pp. 1393-1422.

Beasley, M., Carcello, J., Hermanson, D. and Neal, T. (2009), "The audit committee oversight process", Contemporary Accounting Research, Vol. 26 No. 1, pp. 65-122.

Beck, M. and Mauldin, E. (2014), "Who's really in charge? Audit committee versus CFO power and audit fees", The Accounting Review, Vol. 89 No. 6, pp. 2057-2085.

Bédard, J. and Gendron, Y. (2010), "Strengthening the financial reporting system: can audit committees deliver?", International Journal of Auditing, Vol. 14 No. 2, pp. 174-210.

Bédard, J., Chtourou, S. and Courteau, L. (2004), "The effect of audit committee expertise, independence, and activity on aggressive earnings management", Auditing: A Journal of Practice and Theory, Vol. 23 No. 2, pp. 15-37.

Bonner, B.L., Baumann, M. and Dalal, R.S. (2002), "The effects of member expertise on group decision-making and performance", Organizational Behavior and Human Decision Processes, Vol. 88 No. 2, pp. 719-736.

Boo, E. and Sharma, D. (2008), "Effect of regulatory oversight on the association between internal governance characteristics and audit fees", Accounting and Finance, Vol. 48 No. 1, pp. 51-71.

Bordo, M., Eichengreen, B., Klingebiel, D. and Martinez-Peria, M.S. (2001), "Is the crises problem growing more severe?", Economic Policy, Vol. 16 No. 32, pp. 51-82.

Boschma, R.A. (2005), "Proximity and innovation: a critical assessment", Regional Studies, Vol. 39 No. 1, pp. 61-74.

Bromilow, C. and Keller, D. (2011), "Audit Committee Effectiveness: What Works Best,". 4th ed., The Institute of Internal Auditors Research Foundation, Altamonte Springs, FL.

Brown-Liburd, H. and Wright, A. (2011), "The effect of past client relationship and strength of the audit committee on auditor negotiations", Auditing: A Joumal of Practice and Theory, Vol. 30 No. 4, pp. 51-69.

Bruynseels, L. and Cardinaels, E. (2014), "The audit committee: management watchdog or personal friend of the CEO?”, The Accounting Review, Vol. 89 No. 1, pp. 113-145. 
Carcello, J. and Neal, T.L. (2003), "Audit committee characteristics and auditor dismissals following "new" going concern reports", The Accounting Review, Vol. 78 No. 1, pp. 453-468.

Carcello, J., Hermanson, D. and Ye, Z. (2011), "Corporate governance research in accounting and auditing: insights, practice implications, and future research directions", Auditing: A Journal of Practice and Theory, Vol. 30 No. 3, pp. 1-31.

Carcello, J., Neal, T.L., Palmrose, Z.-V. and Scholz, S. (2011), "CEO involvement in selecting board members, audit committee effectiveness, and restatements", Contemporary Accounting Research, Vol. 28 No. 2, pp. 396-430.

Chung, H. and Kallapur, S. (2003), "Client importance, nonaudit services, and abnormal accruals”, The Accounting Review, Vol. 78 No. 4, pp. 931-955.

Cohen, J.R., Gaynor, L.M., Krishnamoorthy, K. and Wright, A. (2017), "The effects of audit committee ties and industry expertise on investor judgements", Working Paper.

Cohen, J.R., Hoitash, U., Krishnamoorthy, G. and Wright, A. (2014), "The effect of audit committee industry expertise on monitoring the financial reporting process", The Accounting Review, Vol. 89 No. 1, pp. 243-273.

DeAngelo, L.E. (1981), “Auditor size and audit quality”, Journal of Accounting and Economics, Vol. 3 No. 3, pp. 183-199.

DeBoskey, D. and Jiang, W. (2012), "Earnings management and auditor specialization in the post-sox era: an examination of the banking industry", Journal of Banking and Finance, Vol. 36 No. 2, pp. 613-623.

DeFond, M., Raghunandan, K. and Subramanyam, K. (2002), "Do non-audit service fees impair auditor independence? Evidence from going concern audit opinions", Journal of Accounting Research, Vol. 40 No. 4, pp. 1247-1274.

DeZoort, F.T. (1998), "An analysis of experience effects on audit committee members' oversight judgments", Accounting, Organizations and Society, Vol. 23 No. 1, pp. 1-21.

Dhaliwal, D., Naiker, V. and Navissi, F. (2010), "The association between accruals quality and the characteristics of accounting experts and mix of expertise on audit committees", Contemporary Accounting Research, Vol. 27 No. 3, pp. 787-827.

Ettredge, M., Fuerherm, E. and Li, C. (2014), "Fee pressure and audit quality", Accounting, Organizations and Society, Vol. 39 No. 4, pp. 247-263.

Ettredge, M., Xu, Y. and Yi, H.S. (2014), "Fair value measurement and audit fees: evidence from the banking industry", Auditing: A Journal of Practice and Theory, Vol. 33 No. 3, pp. 33-58.

Fields, L.P., Fraser, D.R. and Wilkins, M.S. (2004), "An investigation of the pricing of audit services for financial institutions", Journal of Accounting and Public Policy, Vol. 23 No. 1, pp. 53-77.

Francis, J.R. and Ke, B. (2006), "Disclosure of fees paid to auditors and the market valuation of earnings surprises", Review of Accounting Studies, Vol. 11 No. 4, pp. 495-523.

Frankel, R., Johnson, M. and Nelson, K. (2002), "The relation between auditors' fees for nonaudit services and earnings management”, The Accounting Review, Vol. 77 No. s-1, pp. 71-105.

Habib, A. (2012), "Non-audit service fees and financial reporting quality: a meta-analysis", Abacus, Vol. 48 No. 2, pp. 121-157.

He, X., Pittman, J., Rui, O. and Wu, D. (2017), "Do social ties between external auditors and audit committee members affect audit quality?”, The Accounting Review, Vol. 92 No. 5, pp. 61-87.

Hoitash, U. (2011), "Should independent board members with social ties to management disqualify themselves from serving on the board?", Journal of Business Ethics, Vol. 99 No. 3, pp. 399-423.

Ittonen, K., Miettinen, J. and Vähämaa, S. (2011), "Does female representation in audit committees affect audit fees?", Quarterly Journal of Finance and Accounting, Vol. 49 No. 3, pp. 113-139.

Ittonen, K., Tronnes, P. and Vähämaa, S. (2018), "Do former auditors on the audit committee constrain earnings management? Evidence from the banking industry", Working paper. 
Iyer, V.M. (1998), “Characteristics of accounting firm alumni who benefit their former firm”, Accounting Horizons, Vol. 12 No. 1, pp. 18-30.

Iyer, V.M., Bamber, E.M. and Barefield, R. (1997), "Identification of accounting firm alumni with their former firm: antecedents and outcome”, Accounting, Organizations and Society, Vol. 22 No. 3-4, pp. 315-336.

Jizi, M. and Nehme, R. (2018), "Board monitoring and audit fees: the moderating role of CEO/chair dual roles", Managerial Auditing Journal, Vol. 33 No. 2, pp. 217-243.

Jones, T.M. (1991), "Ethical decision making by individuals in organizations: an issue-contingent model", Academy of Management Review, Vol. 16 No. 2, pp. 366-395.

Kanagaretnam, K., Krishnan, G.V. and Lobo, G.J. (2010), "An empirical analysis of auditor independence in the banking industry", The Accounting Review, Vol. 85 No. 6, pp. 2011-2046.

Kinney, W.R., Palmrose, Z.-V. and Scholz, S. (2004), "Auditor independence, non-audit services and restatements: was the US government right?", Joumal of Accounting Research, Vol. 42 No. 3, pp. 561-588.

Krishnan, G.V. and Visvanathan, G. (2008), "Does the SOX definition of an accounting expert matter? The association between audit committee directors accounting expertise and accounting conservatism", Contemporary Accounting Research, Vol. 25 No. 3, pp. 827-858.

Krishnan, G.V. and Visvanathan, G. (2009), "Do auditors price audit committee's expertise? The case of accounting versus nonaccounting financial experts", Journal of Accounting, Auditing and Finance, Vol. 24 No. 1, pp. 115-144.

Krishnan, J., Sami, H. and Zhang, Y. (2005), "Does the provision of nonaudit services affect investor perceptions of auditor independence?", Auditing: A Joumal of Practice and Theory, Vol. 24 No. 2, pp. 111-135.

Krishnan, J., Wen, Y. and Zhao, W. (2011), "Legal expertise on corporate audit committees and financial reporting quality", The Accounting Review, Vol. 86 No. 6, pp. 2099-2130.

Laeven, L. and Valencia, F. (2013), "Systematic banking crises database", IMF Economic Review, Vol. 61 No. 2, pp. 225-270.

Lähdesmäki, M. and Suutari, T. (2012), "Keeping at arm's length or searching for social proximity? Corporate social responsibility as a reciprocal process between small businesses and the local community", Journal of Business Ethics, Vol. 108 No. 4, pp. 481-493.

Landsman, W.R. and Peasnell, K.V. (2013), "The changing landscape of banking and the challenges it poses for accounting and financial reporting”, Accounting Horizons, Vol. 27 No. 4, pp. 757-773.

Lennox, C. and Park, C. (2007), "Audit firm appointments, audit firm alumni, and audit committee independence”, Contemporary Accounting Research, Vol. 24 No. 1, pp. 235-258.

Mael, F. and Ashforth, B.E. (1992), "Alumni and their alma mater: a partial test of the reformulated model of organizational identification”, Joumal of Organizational Behavior, Vol. 13 No. 2, pp. 103-123.

Marxen, D.E. (1996), “The big 6 experience: a retrospective account by alumni”, Accounting Horizons, Vol. 10 No. 2, pp. 73-87.

Mattes, J. (2012), "Dimensions of proximity and knowledge bases: innovation between spatial and nonspatial factors", Regional Studies, Vol. 46 No. 8, pp. 1085-1099.

Menon, K. and Williams, D.D. (2004), "Former audit partners and abnormal accruals", The Accounting Review, Vol. 79 No. 4, pp. 1095-1118.

Mitra, S. (2007), "Nonaudit service fees and auditor independence: empirical evidence from the oil and gas industry", Journal of Accounting, Auditing and Finance, Vol. 22, pp. 85-107.

Naiker, V. and Sharma, D.S. (2009), "Former audit partners on the audit committee and internal control deficiencies", The Accounting Review, Vol. 84 No. 2, pp. 559-587.

Naiker, V., Sharma, D.S. and Sharma, V.D. (2013), "Do former audit firm partners on audit committees procure greater nonaudit services from the auditor?", The Accounting Review, Vol. 88 No. 1, pp. 297-326. 
New York Stock Exchange (NYSE) (2009). "Listed company manual. Rule 303A.07: audit committee additional requirements", available at: http://nysemanual.nyse.com/LCM/

Nooteboom, B. (1999), "Innovation and inter-firm linkages: new implications for policy", Research Policy, Vol. 28 No. 8, pp. 793-805.

Public Company Accounting Oversight Board (PCAOB) (2011), "Testimony concerning the role of the accounting profession in preventing another financial crisis", Chairman James R. Doty's speech at the United States Senate Committee on Banking, Housing and Urban Affairs, Subcommittee on Securities, Insurance, and Investment, April 6. Washington, DC.

Schmidt, J. and Wilkins, M.S. (2013), "Bringing darkness to light: the influence of auditor quality and audit committee expertise on the timeliness of financial statement restatement disclosures", Auditing: A Journal of Practice and Theory, Vol. 32 No. 1, pp. 221-244.

Securities and Exchange Commission (SEC) (2003a). "Standards related to listed company audit committees", SEC Release No. 33-8220., Government Printing Office, Washington, DC D.C. available at: www.sec.gov/rules/final/33-8220.htm

Securities and Exchange Commission (SEC) (2003b), "NASD and NYSE Rulemaking: Relating to Corporate Governance,", SEC Release No. 34-48745, November 4, Government Printing Office, Washington, DC.

Seetharaman, A., Xu, W. and Sanjian, Z. (2014), "An empirical analysis of the effects of accounting expertise in audit committees on non-GAAP earnings exclusions", Accounting Horizons, Vol. 28 No. 1, pp. 17-37.

Srinidhi, B.N. and Gul, F.A. (2007), "The differential effects of auditors' non-audit and audit fees on accrual quality", Contemporary Accounting Research, Vol. 24 No. 2, pp. 595-629.

Tanyi, P.N. and Smith, D.B. (2015), "Busyness, expertise, and financial reporting quality of audit committee chairs and financial experts", Auditing: A Journal of Practice and Theory, Vol. 34 No. 2, pp. 59-89.

Turner, L. (2001), "Audit committees: a roadmap for establishing accountability", Remarks to Conference Sponsored by Washington, DC University School of Law and the Institute for Law and Economic Policy, Scottsdale, AZ, March 10.

U.S House of Representatives (2002), "The Sarbanes-Oxley Act of 2002, ", Public Law 107-204 [H.R. 3763]. Washington, DC, D.C: Government Printing Office.

Unger, L.S. (2001), "This year's proxy season: sunlight shines on auditor independence and executive compensation", Speech of Acting SEC Chairman, US Securities and Exchange Commission. June 25, SEC, Washington, DC.

Uzzi, B. (1997), "Social structure and competition in interfirm networks: the paradox of embeddedness", Administrative Science Quarterly, Vol. 42 No. 1, pp. 35-67.

Whisenant, S., Sankaraguruswamy, S. and Raghunandan, K. (2003), "Evidence on the joint determination of audit and nonaudit fees", Journal of Accounting Research, Vol. 41 No. 4, pp. 721-744.

Wildermuth, C., De Mello e Souza, C. and Kozitza, T. (2017), "Circles of ethics: the impact of proximity on moral reasoning", Journal of Business Ethics, Vol. 140 No. 1, pp. 17-42.

Wooldridge, J. (2009), “Introductory Econometrics”, 4th ed. Cengage Learning.

\section{Corresponding author}

Kim Ittonen can be contacted at: kim.ittonen@hanken.fi

Banks' audit committees 